\title{
DNA Cleavage Patterns as Indicators of Genotypic Heterogeneity among Strains of Acholeplasma and Mycoplasma Species
}

\author{
By S. RAZIN, ${ }^{1 \dagger}$ J. G. TULLY, ${ }^{2}$ D. L. ROSE, ${ }^{2}$ AND M. F. BARILE ${ }^{1 *}$ \\ ${ }^{1}$ Mycoplasma Branch, National Center for Drugs and Biologics, Food and Drug Administration, \\ Bethesda, Maryland 20205, U.S.A. \\ ${ }^{2}$ Mycoplasma Section, Laboratory of Molecular Microbiology, National Institute of Allergy and \\ Infectious Diseases, Frederick, Maryland 21701, U.S.A.
}

(Received 31 August 1982; revised 21 October 1982)

\begin{abstract}
Electrophoretic patterns of digestion products of Acholeplasma and Mycoplasma DNA by restriction endonucleases were compared. The patterns of Acholeplasma axanthum strains isolated from a variety of hosts and habitats differed markedly from each other, indicating considerable genotypic heterogeneity among strains included in this species. Heterogeneity was less marked among the Acholeplasma oculi strains tested, and was minimal among strains of the avian pathogen Mycoplasma gallisepticum. Strains of Mycoplasma genitalium isolated from the urethra of patients with non-gonococcal urethritis and from the urethra of an experimentally infected chimpanzee yielded identical cleavage patterns, indicating a high degree of genetic homogeneity of these strains. The data support the notion that mycoplasma species of strict host and tissue specificity exhibit marked genetic homogeneity. The advantages and deficiencies of the use of DNA cleavage patterns for classification purposes are discussed.
\end{abstract}

\section{INTRODUCTION}

The current concept of species in prokaryotes is ill-defined. Ideally, a prokaryotic species should consist of a cluster of strains of identical or nearly identical genetic composition. However, it is apparent that in the process of evolution, mutagenesis and selective pressures have resulted in the appearance of strains differing genotypically to varying degrees from the original strain, a factor which constitutes the major obstacle in bacterial classification. In practice, most prokaryotic species have been established on the basis of a few, readilydetermined phenotypic characteristics, in the absence of supportive genetic data. In most cases this somewhat arbitrary speciation proved to be effective, serving the purpose of distinguishing bacteria of special medical, industrial and agricultural importance. Nevertheless, it is clear that in order to put bacterial classification on a more scientific basis, speciation should be determined according to genetic relatedness. Direct analysis of the base composition and nucleotide sequence of the bacterial chromosome may provide the necessary data. A variety of DNA-DNA hybridization techniques have been employed in assessment of genetic relatedness among prokaryotic strains, as these provide a measure of the degree of homology of nucleotide sequences between the chromosomes of the tested organisms. DNA base composition analysis and hybridization tests have indeed become useful tools in classification of prokaryotes, including mycoplasmas (Somerson et al., 1967; Aulakh et al., 1979, 1983; Stephens et al., 1983).

We have recently promoted the use of cleavage patterns of mycoplasmal DNA digested by restriction endonucleases as 'finger-prints' indicating genetic relatedness among mycoplasma strains (Razin et al., 1983; Chandler et al., 1982). These enzymes cleave double-stranded DNA at specific recognition sites consisting of four or six nucleotides arranged in a specific order. The

$\dagger$ Present address: Department of Membrane and Ultrastructure Research, The Hebrew University-Hadassah Medical School, Jerusalem 91010, Israel. 
electrophoretic patterns of the resulting oligonucleotide fragments exhibit highly reproducible patterns specific for strains and species. By using this method nine serotypes of Ureaplasma urealyticum were shown to fall in two distinct clusters representing apparently two genotypes, whereas the DNA from five representative strains of Mycoplasma pneumoniae produced very similar cleavage patterns indicating the marked genetic homogeneity of this species (Chandler et al., 1982; Razin et al., 1983). Species specific cleavage patterns were also reported for the DNA of Spiroplasma citri strains cleaved by EcoRI (Bove \& Saillard 1979; Bove et al., 1982) and for Mycoplasma hyorhinis DNA digested by a variety of restriction endonucleases (Darai et al., 1981, 1982).

Recent DNA-DNA hybridization tests (Aulakh et al., 1983) revealed low nucleotide sequence homology ( 2 to $21 \%$ ) among the eight established species of Acholeplasma, providing genetic support for their distinction. However, considerable variation in nucleic acid homology (ranging between 48 to $100 \%$ ) was found among strains within each of the species Acholeplasma laidlawii and Acholeplasma axanthum (Stephens et al., 1983). It seemed worthwhile to test whether or not this intraspecies genotypic heterogeneity can be observed by the restriction endonuclease method. Strains of $A$. axanthum, for which hybridization data were available, were selected for our study. Strains of Acholeplasma oculi, the avian pathogen Mycoplasma gallisepticum and the newly discovered human genital mycoplasma Mycoplasma genitalium (Tully et al., 1981, 1983) were also included. The data presented here show that DNA cleavage patterns can be used as a convenient measure of intraspecies genotypic homogeneity or heterogeneity and support the notion that mycoplasma species of strict host and tissue specificity exhibit marked genetic homogeneity.

\section{METHODS}

Organisms and growth conditions. The designation of the strains tested and their origin are listed in Table 1. All the strains were cloned by the filtration procedure (Subcommittee on the Taxonomy of Mollicutes, 1979). The acholeplasmas and the Mycoplasma gallisepticum strains were grown in 200-400 ml quantities of $1 \%(\mathrm{w} / \mathrm{v})$ bovine serum fraction broth medium (Tully \& Razin, 1969) for $24-48 \mathrm{~h}$ at $37^{\circ} \mathrm{C}$, and harvested by centrifugation at 27000 $\mathrm{g}$ for $30 \mathrm{~min}$ at $4{ }^{\circ} \mathrm{C}$. The cell pellets of the acholeplasmas were washed once in $0.25 \mathrm{M}-\mathrm{NaCl}$ containing $0.1 \mathrm{M}-$ $\mathrm{Na}_{2}$ EDTA while those of $M$. gallisepticum were washed in $0.25 \mathrm{M}-\mathrm{NaCl}$ alone. The washed pellets were kept at $-70^{\circ} \mathrm{C}$ until used for DNA extraction. The Mycoplasma genitalium strains were grown in plastic tissue culture flasks (T-175) containing $200 \mathrm{ml} \mathrm{SP} 4$ medium (Tully et al., 1977). The bottles were incubated horizontally at $37^{\circ} \mathrm{C}$ for $88 \mathrm{~h}$. The medium was decanted and the surface attached growth was washed twice with $10 \mathrm{ml} 0 \cdot 25 \mathrm{M}-\mathrm{NaCl}$ and then scraped off into another $10 \mathrm{ml}$ of the salt solution. The organisms were collected by centrifugation at $18000 \mathrm{~g}$ for $10 \mathrm{~min}$, and the cell pellets were used immediately for DNA extraction.

DNA extraction and purification. Portions of the washed cell pellets (containing about $20-50 \mathrm{mg}$ cell protein) were resuspended in $0.1 \mathrm{ml}$ TE buffer (50 mM-Tris, pH 8.0 and $10 \mathrm{~mm}$-EDTA) and the organisms were lysed by adding $1 \mathrm{ml} 1 \%(\mathrm{w} / \mathrm{v})$ SDS in TE buffer. To minimize self-digestion of DNA by the endogenous DNAases of acholeplasmas (Razin et al., 1964; Pollack et al., 1965) the concentration of EDTA in the TE buffer was raised to $20 \mathrm{~mm}$ when acholeplasma pellets were lysed. The lysate was treated for $30 \mathrm{~min}$ at $37^{\circ} \mathrm{C}$ with preheated (boiled for $2 \mathrm{~min}$ ) RNAase A (Worthington Biochemical Corporation) at a final concentration of $50 \mu \mathrm{g} \mathrm{ml}^{-1}$, and then for 60 min at $37^{\circ} \mathrm{C}$ with preheated proteinase $\mathrm{K}$ (Boehringer) at $100 \mu \mathrm{g} \mathrm{ml}^{-1}$. The SDS in the lysate was then precipitated by adding $100 \mu \mathrm{l} 5 \mathrm{M}$-potassium acetate and incubated in ice for $30 \mathrm{~min}$. The precipitate was sedimented by centrifugation at 15000 r.p.m. for $10 \mathrm{~min}$ in an Eppendorf microcentrifuge. The supernatant fluid was transferred to another microcentrifuge tube and mixed with an equal volume of redistilled phenol/chloroform $(1: 1, \mathrm{v} / \mathrm{v})$ mixture. The aqueous phase was separated by centrifugation at 15000 r.p.m. for $15 \mathrm{~min}$ in the microcentrifuge and the DNA was precipitated by adding two volumes of cold ethanol. The DNA precipitate was collected by centrifugation for $5 \mathrm{~min}$ in the microcentrifuge. The resulting pellet was dried under vacuum and dissolved in 25$100 \mu 10 \mathrm{~mm}$-Tris, $\mathrm{pH} 7.5$ containing $1 \mathrm{~mm}-\mathrm{Na}_{2}$ EDTA. A sample $(5 \mu \mathrm{l})$ of the DNA solution was diluted with $0.8 \mathrm{ml}$ phosphate-buffered saline, and the absorbance was measured at 260 and $280 \mathrm{~nm}$. The values of $A_{260} / A_{280}$ were about 1.7 to $2 \cdot 0$, indicating the purity of the DNA preparations. The DNA content of the original solution was calculated according to the $A_{260}$ value of the diluted solution, assuming that an $A_{260}$ of 1.0 corresponds to $50 \mu \mathrm{g} \mathrm{DNA} \mathrm{ml}{ }^{-1}$ (Archer et al., 1981).

DNA digestion. Restriction endonucleases were purchased from New England Biolabs (Beverley, Mass.). The reaction mixtures (total volume $20 \mu \mathrm{l}$ ) contained about $5 \mu \mathrm{g}$ mycoplasmal DNA, 20-40 units of the tested endonuclease, $10 \mathrm{~mm}$-Tris/ $\mathrm{HCl}, \mathrm{pH} 7 \cdot 5,10 \mathrm{~mm}-\mathrm{MgSO}_{4}$ and $50 \mathrm{~mm}-\mathrm{NaCl}$ for digestion by Bam HI, Pst I and 
Table 1. Designation and origin of strains tested

Species and strain designation

Acholeplasma oculi

$19 \mathrm{~L}$

3557 TC

Goat 5

70-538 TC

X5045

75151

Acholeplasma axanthum

S-743

1190

D-1

H86N

$1025 \mathrm{C}$

0501

J544

J248

Acholeplasma laidlawii

Mycoplasma gallisepticum

PG31 (x95)
S6
F(R)

293-1

Mycoplasma genitalium

G-37*

G-37 (chimp)†

M-30
Isolated from:

Isolated by:

J. M. Al-Aubaidi

Goat, eye

Tissue culture

Goat, eye

Tissue culture

Swine, nasal

Guinea pig, genital tract

Tissue culture

Lagoon

Swine, joint

Bovine, nasal

Kale

Broccoli

Coconut palm

Coconut palm

Sewage

Chicken, trachea

Turkey, brain

Chicken, trachea

Chicken, trachea

Man, genital tract

Chimpanzee, genital tract

(experimentally infected)

Man, genital tract
R. A. DelGiudice

O. H. V. Stalheim

R. A. DelGiudice

R. F. Ross

E. V. Langford

C. Friend

R. F. Ross

D. Schimmel

N. O. Olson

N. L. Somerson

N. L. Somerson

S. J. Eden-Green

S. J. Eden-Green

P. P. Laidlaw \&

W. J. Elford

F. S. Markham

D. V. Zander

R. Yamamoto \&

H. E. Adler

J. Taylor

J. G. Tully \&

D. Taylor-Robinson

J. G. Tully \&

M. F. Barile

J. G. Tully \&

D. Taylor-Robinson
Received from:

J. M. Al-Aubaidi

R. A. DelGiudice

O. H. V. Stalheim

R. A. DelGiudice

R. F. Ross

E. V. Langford

J. G. Tully

R. F. Ross

L. Stipkovits

J. G. Tully

N. L. Somerson

N. L. Somerson

S. J. Eden-Green

S. J. Eden-Green

D. G. ff. Edward

Reference reagent NIH

J. Noel

J. Fabricant

J. Fabricant

J. G. Tully

J. G. Tully

J. G. Tully

* Isolated from the urethra of a non-gonococcal urethritis patient in SP4 broth at $37{ }^{\circ} \mathrm{C}$ (Tully et al., 1981). Two cloned cultures were tested, one at passage level 8 and the other at 17 .

$\dagger$ Isolated on SP4 medium (passage 1) from the urethra of a chimpanzee 8 weeks after experimental intraurethral infection with the G-37 cloned strain at passage 8 .

$\ddagger$ Isolated from the urethra of another non-gonococcal urethritis patient on SP4 broth at $30^{\circ} \mathrm{C}$, cloned and tested at the fourth passage.

HindIII, and $50 \mathrm{~mm}-\mathrm{Tris} / \mathrm{HCl}, \mathrm{pH} 7 \cdot 5,10 \mathrm{~mm}-\mathrm{MgSO}_{4}$ and $100 \mathrm{~mm}-\mathrm{NaCl}$ for $\mathrm{XhoI}$. For the enzymes $\mathrm{HpaI}$ and $K p n I$, the salt solution was composed of $10 \mathrm{~mm}-\mathrm{Tris} / \mathrm{HCl}, \mathrm{pH} \mathrm{7.5}$, and $10 \mathrm{mM} \mathrm{MgSO}$, and for $S m a \mathrm{I}$, the solution contained in addition $20 \mathrm{mM}-\mathrm{KCl}$. A reaction mixture containing the tested endonuclease, the appropriate salt solution and $1 \mu \mathrm{g}$ of phage lambda DNA (Bethesda Research Laboratories, BRL, Gaithersburg, Md.) served as a control of specific enzyme activity. Digestions were carried out at $37^{\circ} \mathrm{C}$ for $60 \mathrm{~min}$. The reaction was stopped by adding $2 \mu \mathrm{l}$ of tracking dye solution consisting of $0.07 \%(\mathrm{w} / \mathrm{v})$ bromophenol blue, $7 \%(\mathrm{w} / \mathrm{v})$ SDS, and $33 \%(\mathrm{v} / \mathrm{v})$ glycerol in water.

Electrophoresis of digestion products. The total volume of the reaction mixture was subjected to electrophoresis in slab gels made of $1 \%(\mathrm{w} / \mathrm{v})$ agarose (Type 1, Low EEO; Sigma) prepared in Tris/borate buffer (89 mM-Tris, pH $8 \cdot 2,2 \cdot 5 \mathrm{~mm}$-EDTA, and $89 \mathrm{~mm}$-boric acid) used also as electrophoresis buffer. A vertical electrophoresis apparatus (BRL, model V16) was used at 100 volts for $3 \mathrm{~h}$ until the dye marker reached the bottom of the gel. The gel was stained for 15 min with ethidium bromide $\left(0.4 \mu \mathrm{g} \mathrm{ml}^{-1}\right)$ and photographed under UV light (Chromato-Vue transilluminator model C-61, Ultra-Violet Products, San Gabriel, Calif.) using Polaroid type $55 \mathrm{P} / \mathrm{N}$ film and a Polaroid MP-4 land camera with an orange filter. The negatives obtained were used to prepare prints in which the polynucleotide bands appear dark on a light background. A control preparation of undigested DNA (DNA preparations without the addition of restriction endonucleases) from each mycoplasma was also subjected to electrophoresis to detect extrachromosomal DNA. Only one chromosomal band was seen with no evidence of extrachromosomal DNA by the electrophoretic procedure. 


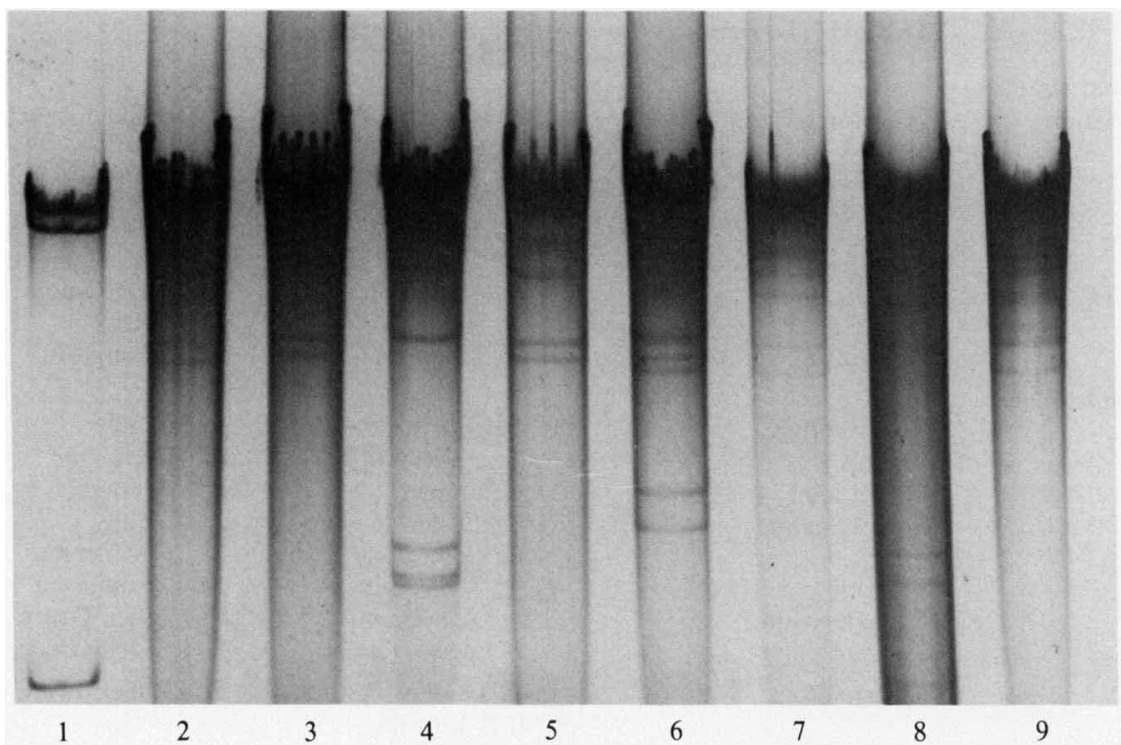

Fig. 1. Cleavage patterns of the DNA of A. axanthum strains (lanes 2-9) and of phage lambda DNA (lane 1) digested by $K p n I$. The strains tested were S-743 (lane 2); 0501 (lane 3); D-1 (lane 4); 1025C (lane 5); H86N (lane 6); J544 (lane 7); 1190 (lane 8) and J248 (lane 9). Of the eight strains tested, the patterns of only strains 0501 and $1025 \mathrm{C}$ (both isolated from vegetables) appear similar. The 'smears' seen in the gels indicate that some degradation of DNA occurred during DNA extraction.

\section{RESULTS}

The DNA cleavage patterns of Acholeplasma axanthum strains, particularly those obtained with restriction endonucleases with recognition sites rich in $\mathrm{G}+\mathrm{C}$, support the intraspecies genetic heterogeneity of this species indicated by the DNA hybridization data (Stephens et al., 1983). Thus, of the eight $A$. axanthum strains tested only the DNA of strains 0501 and $1025 \mathrm{C}$ (both isolated from vegetables, Table 1) produced identical cleavage patterns with $K p n I$ (recognition site GGTAC/C) and with BamHI (recognition site G/GATCC), whereas the DNAs of the other six strains each yielded a different pattern (Figs 1 and 2). On the other hand, the cleavage patterns of the DNAs of the five $A$. oculi strains by $K p n I$ and $B a m H I$, though not being identical, resembled each other (Fig. 3). In addition, Fig. 3 shows that the $A$. oculi DNAs can be distinguished from those of $A$. axanthum in being cleaved at many more points when digested with $K p n I$, and the cleavage pattern of the $A$. laidlawii PG8 DNA by this enzyme differs from the patterns of the $A$. axanthum and $A$. oculi strains. Pst $\mathrm{I}$, despite sharing with BamHI and $K p n I$ a recognition site rich in $\mathrm{G}+\mathrm{C}(\mathrm{CTGCA} / \mathrm{G})$ cleaved the acholeplasmal DNAs at many points, producing highly similar patterns with the $A$. oculi strains, but different patterns with the $A$. axanthum and $A$. laidlawii strains (Fig. 4).

The restriction endonucleases $H p a I$ and $H$ ind III which have recognition sites poor in $\mathrm{G}+\mathrm{C}$ (GTT/AAC and A/AGCTT, respectively) cut the $\mathrm{G}+\mathrm{C}$ poor acholeplasmal DNA at many sites, producing cleavage patterns with numerous bands, making comparison of patterns more difficult. Again, the patterns of the $A$. axanthum strains obtained with these enzymes differed from each other, as against the similarity of patterns exhibited by the selected $A$. oculi strains tested (data not shown). On the other hand, digestion of the acholeplasmal DNAs by XhoI (recognition site C/TCGAG) produced patterns with no or very few visible cleavage bands, rendering this enzyme not useful for our purpose. SmaI, the enzyme with a recognition site $\mathrm{CCC} / \mathrm{GGG}$, did not produce any visible cleavage fragments when applied to the DNAs of the five $A$. oculi strains, and three of the A. axanthum strains (D-1, 1190, and S743) but produced four visible cleavage bands with $A$. laidlawii PG8 DNA (data not shown). 


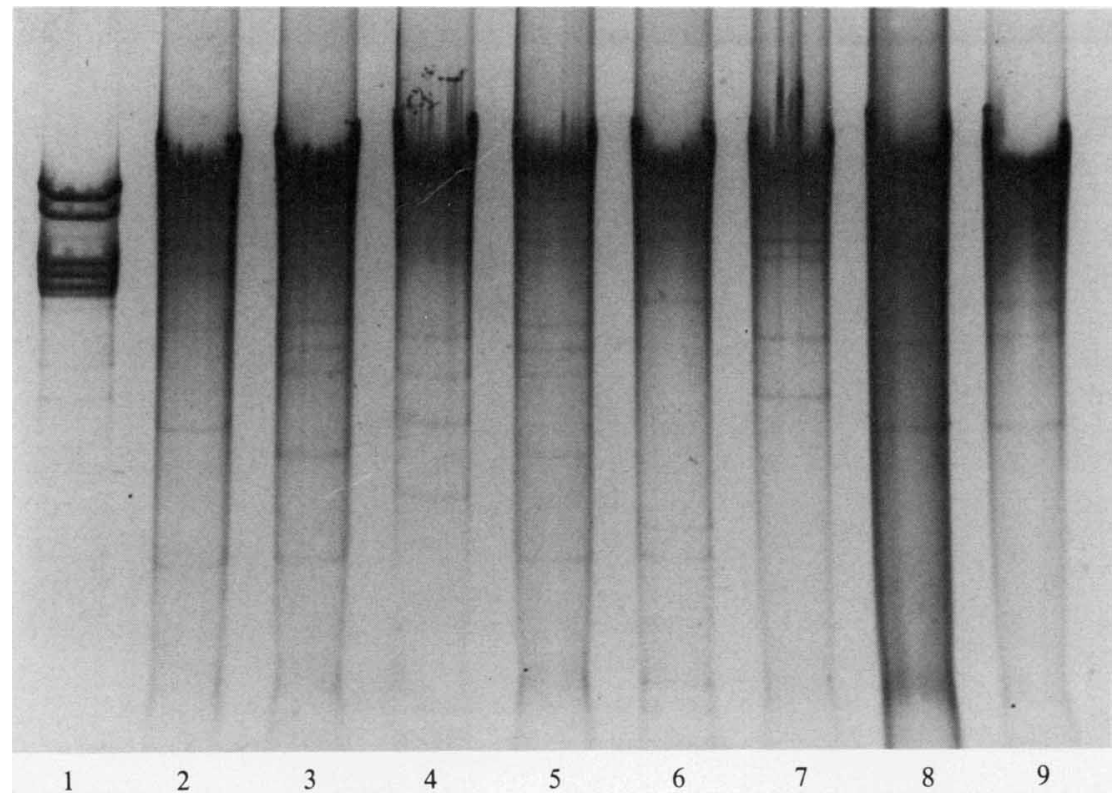

Fig. 2. Cleavage patterns of the DNA of A. axanthum strains (lanes 2-9) and of phage lambda DNA (lane 1) digested by BamHI. The order of the strains in the lanes is as depicted in Fig. 1. Only strains 0501 and $1025 \mathrm{C}$ produced similar or identical patterns.

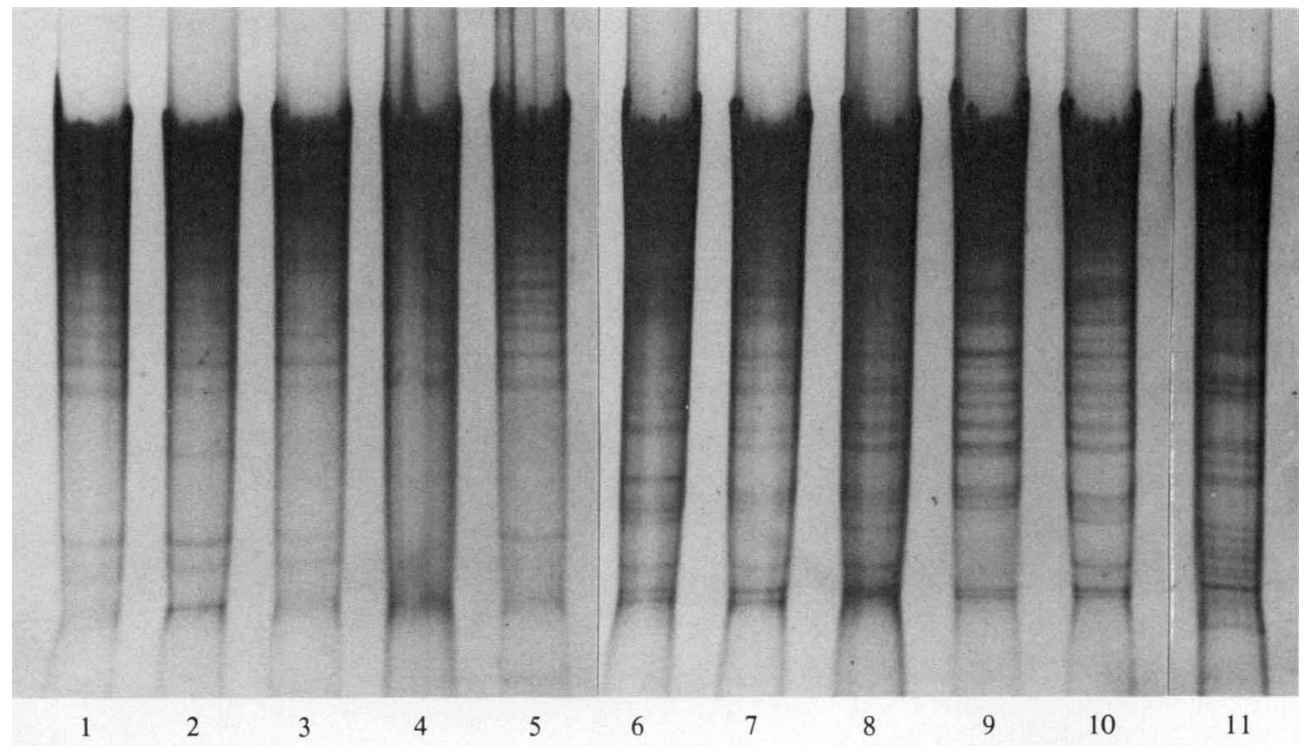

Fig. 3. Cleavage patterns of the DNA of A. oculi strains by BamHI (lanes 1-5) and by KpnI (lanes 6-10). The cleavage pattern of $A$. laidlawii PG8 DNA by KpnI is included for comparison in lane 11. The $A$. oculi strains tested were: 19L (lane 1); 3557TC (lanes 2 and 6); goat 5 (lanes 3 and 7); 70-538TC (lanes 4 and 8); X5054 (lanes 5 and 9) and 75151 (lane 10). 


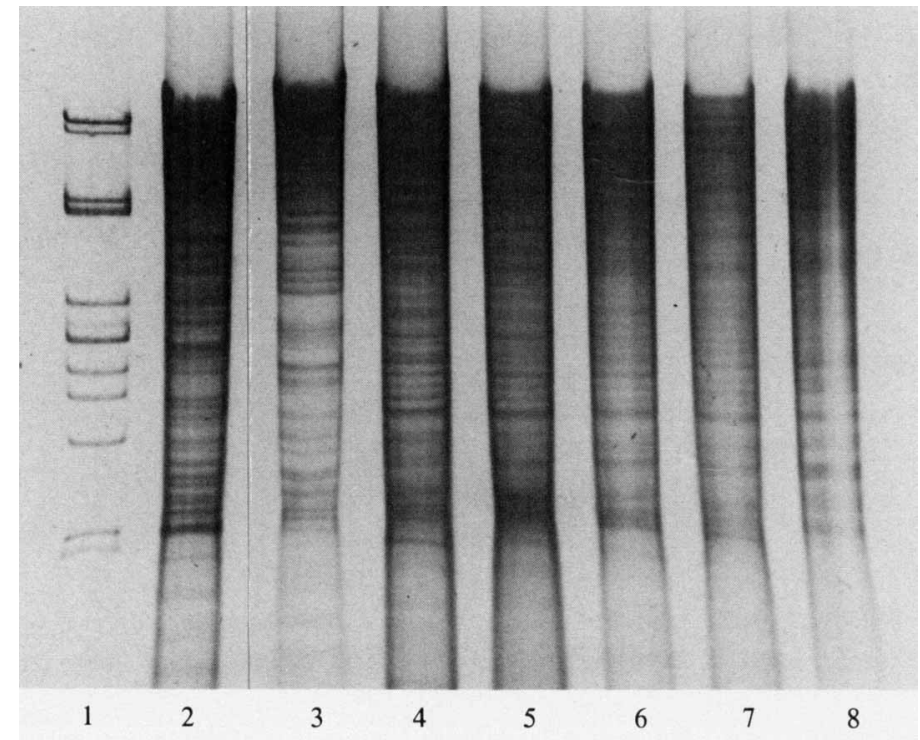

Fig. 4. Cleavage patterns of phage lambda DNA (lane 1) and the DNAs of $\boldsymbol{A}$. laidlawii PG8 (lane 2), $\boldsymbol{A}$. axanthum D-1 (lane 3 ) and $A$. oculi strains (lanes 4-8) digested by $P$ stI. The $A$. oculi strains tested were: X5045 (lane 4); 70-538TC (lane 5); goat 5 (lane 6); 3557TC (lane 7) and 19L (lane 8). The marked similarity of the $A$. oculi patterns to each other, and their dissimilarity to the $A$. axanthum and $A$. laidlawii patterns can be seen.

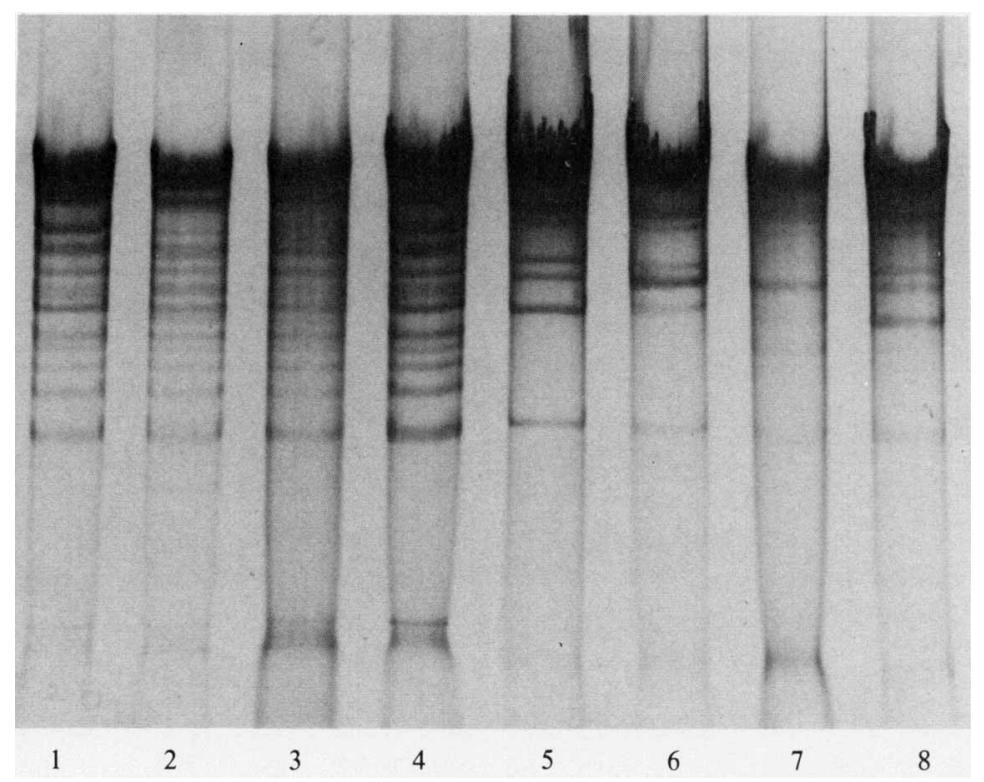

Fig. 5. Cleavage patterns of the DNA of $M$. gallisepticum strains by BamHI (lanes 1-4) and by $K p n \mathbf{I}$ (lanes 5-8). The strains tested were: PG-31 (lanes ! and 5); S6 (lanes 2 and 6); F(R) (lanes 3 and 7) and strain 293-1 (lanes 4 and 8 ). The marked similarity of the patterns is particularly noticeable with BamHI. The patterns of strains PG-31 and 293-1 are practically identical with both enzymes. 


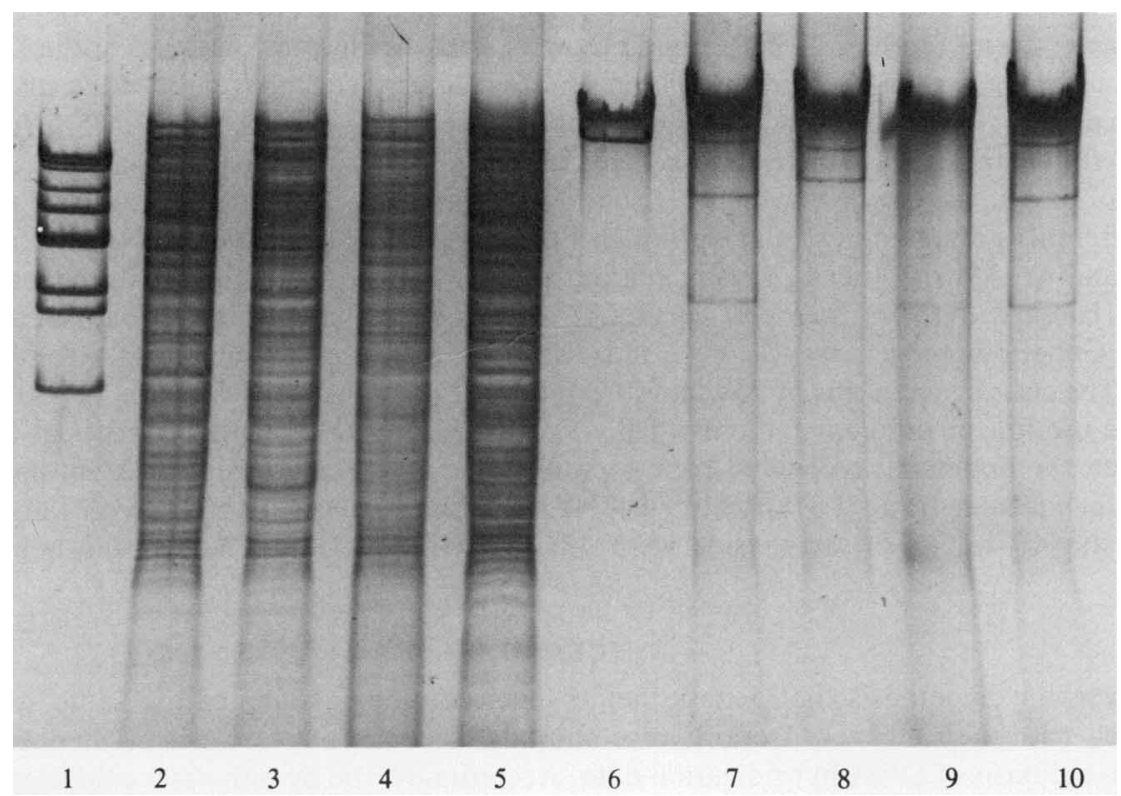

Fig. 6. Cleavage patterns of lambda phage DNA and DNAs of $M$. gallisepticum strains by HpaI (lanes 1-5) and by Xhol (lanes 5-10). The strains tested: PG-31 (lanes 2 and 7); S6 (lanes 3 and 8), F(R) (lanes 4 and 9) and 293-1 (lanes 5 and 10). The essential identity of the patterns of strains PG-31 and 293-1 can be seen.

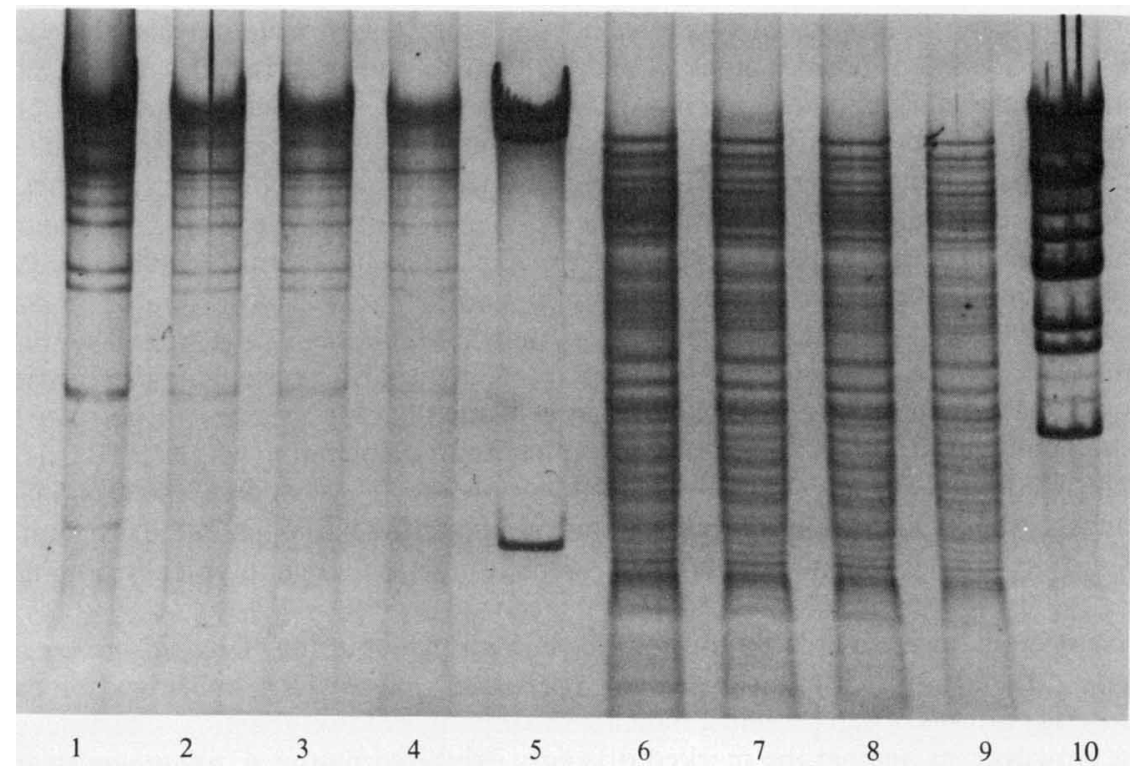

Fig. 7. Cleavage patterns of the DNA of $M$. genitalium strains and of phage lambda DNA by KpnI (lanes 1-5) and by $\mathrm{HpaI}$ (lanes 6-10). The strains tested: G-37, passage 17 (lanes 1 and 6); G-37, passage 8 (lanes 2 and 7); G-37 isolated from the urethra of an experimentally infected chimpanzee (lanes 3 and 8): M-30, passage 4; lambda phage DNA (lanes 5 and 10). The identity of the cleavage patterns of all strains can be seen with both enzymes. 
Based on the known close serologic relatedness, similarities in electrophoretic patterns of cell proteins (Razin \& Rottem, 1967; Rhoades et al., 1974) and narrow host specificity of $M$. gallisepticum strains (Jordan, 1979) we had predicted that the cleavage patterns of the DNAs of the various $M$. gallisepticum strains would be similar. This, indeed, proved to be the case, as the cleavage patterns of the DNAs of the four M. gallisepticum strains by BamHI (Fig. 5), HpaI (Fig. 6) and PstI (data not shown) were almost identical. Nevertheless, the cleavage patterns obtained with $X h o I$ and $K p n I$, enzymes which cut the $M$. gallisepticum DNA at fewer points, revealed some differences among the strains, although PG-31 and 293-1 appeared identical in all cases (Figs 5 and 6). As with the $A$. axanthum and $A$. oculi DNAs, SmaI failed to produce visible cleavage bands with the $M$. gallisepticum DNA, apart from one band with the S6 DNA (data not shown). Genetic homogeneity was even more striking with the human genital $M$. genitalium strains. The cleavage patterns by $K p n \mathrm{I}$ and $H p a \mathrm{I}$ of the DNA of strains G-37 and M-30 isolated from the urethra of different patients (Tully et al., 1981) were essentially identical (Fig. 7). Moreover, the organisms recovered from a chimpanzee 8 weeks after it had been inoculated with $M$. genitalium strain G-37, exhibited DNA cleavage patterns identical with those of the original strain (Fig. 7). The same results were obtained with Bam HI and PstI (results not shown).

\section{DISCUSSION}

The working hypothesis that genetic heterogeneity among strains of the same species is associated with their recovery from diverse habitats has been put forward by Stephens et al. (1983) on the basis of DNA hybridization data. Accordingly, the hypothesis would suggest that adaptation of an organism to a new host had pressured it to genotypically change in order to survive or that colonization occurred through a selective process. The DNA cleavage data reported here support the above notion by demonstrating the marked genotypic heterogeneity of the $A$. axanthum strains isolated from a variety of hosts (Table 1). The $A$. oculi strains, though appearing closer in DNA structure to each other than the $A$. axanthum strains, still exhibit significant variations in their cleavage patterns, a fact which may be related to the variety of hosts from which the $A$. oculi strains were isolated (Table 1). Unfortunately, in the case of $A$. oculi DNA hybridization data are unavailable for comparison with the DNA cleavage data.

In contrast to the marked heterogeneity of the two Acholeplasma species, the DNA cleavage patterns of $M$. gallisepticum strains indicated marked genetic homogeneity, despite the fact that the strains were isolated in different laboratories, and were subcultured numerous times. It can be argued in this case that $M$. gallisepticum has a much more restricted ecological niche than the acholeplasmas, as it only inhabits the respiratory tract of chickens and turkeys (Jordan, 1979). In genetic homogeneity, $M$. gallisepticum resembles another avian pathogen $M$. meleagridis (Elmahi et al., 1982) and the human respiratory pathogen $M$. pneumoniae (Chandler et al., 1982; Razin et al., 1983). In the case of $M$. pneumoniae the ecological niche is even more restricted, as this mycoplasma is found in the respiratory tract of man only. Mycoplasma pneumoniae has not been isolated under natural conditions from any other animal, including primates (Barile, 1973). Data on the occurrence of $M$. genitalium are still very scarce. Nevertheless, the DNA cleavage patterns suggest that this mycoplasma, considered as a potential pathogen in the urogenital tract (Tully et al., 1981 ; Taylor-Robinson et al., 1981) constitutes another genotypically homogeneous species.

DNA cleavage data are available for another human mycoplasma, Ureaplasma urealyticum (Razin et al., 1983). In this case, the cleavage patterns, as well as DNA hybridization data and electrophoretic patterns of cell proteins, indicate the presence of two genetically distinct clusters of strains. However, as against the marked diversity exhibited by the $A$. axanthum strains, the strains in each of the two $U$. urealyticum clusters show remarkable homogeneity.

The experience gained so far from the use of restriction endonucleases for classification purposes enables the drawing of some conclusions as to the advantages and deficiencies of this approach. The advantages include: (1) Need for a small quantity of organisms, as only a few $\mu \mathrm{g}$ of DNA suffice for each test. (2) No interference by culture medium components particularly proteins, a problem complicating the electrophoretic analysis of cell proteins of poorly-growing 
mycoplasmas in serum-rich media (see Razin et al., 1983). (3) Easy reading of results based on visual comparison of patterns. Densitometer tracings of the patterns can also be prepared (Bove et al., 1982). (4) The DNA cleavage patterns are excellent tools to test for genetic homogeneity. Identical patterns obtained by several restriction enzymes strongly indicate genetic homogeneity of subcultures. The case of the $M$. genitalium strains illustrates this point. Also, the susceptibility of the DNA of a tested strain to cleavage by restriction endonucleases with $\mathrm{G}+\mathrm{C}$ rich recognition sites, provides an indication for assessment of the $\mathrm{G}+\mathrm{C}$ content of this particular DNA. Thus, the relatively $\mathrm{G}+\mathrm{C}$ rich $M$. pneumoniae DNA ( $\mathrm{G}+\mathrm{C}$ about $40 \mathrm{~mol} \%$ ) is cleaved by $S m a \mathrm{I}$ (recognition site CCC/GGG) at about 35 sites, whereas the DNAs of other Mycoplasma and Acholeplasma species, which are poorer in $\mathrm{G}+\mathrm{C}$, usually resist digestion by this enzyme (present results and Razin et al., 1983).

Possible deficiencies of the DNA cleavage approach can be summarized as follows: (1) Undegraded DNA of high purity is required. This is not easy to obtain with the Acholeplasma species, as they are particularly rich in endogenous DNAases which are activated on cell lysis (Razin et al., 1964; Pollack et al., 1965). We found that by increasing the EDTA concentration in the lysis solution, and by processing relatively small pellets of cells, the self-digestion of the mycoplasmal DNA can be minimized. We have not encountered this problem with Mycoplasma species. (2) The presence of extrachromosomal DNA, such as that of plasmids or viruses, complicates the interpretation of cleavage patterns (Bove et al., 1982). It can be argued that the cleavage patterns of $A$. axanthum strains are so different from each other due to the presence of different plasmids and/or viruses in these strains. Although this possibility cannot be totally ruled out, electrophoresis of undigested DNA of these strains failed to show any bands additional to that of the chromosomal DNA. (3) Comparison of cleavage patterns is done visually by direct comparison of bands on photographs or on densitometer tracings of the photographs. This suffices for determining complete identity, close-similarity, or total nonidentity of DNA structure. The problem lies in cases of partial similarity, as the cleavage data are not expressed by numbers, such as percent homology provided by DNA hybridization tests.

\section{REFERENCES}

ARCher, D. B., Best, J. \& BARber, C. (1981). Isolation and restriction mapping of a spiroplasma plasmid. Journal of General Microbiology 126, 511-514.

aulakh, G. S., Tully, J. G. \& Barile, M. F. (1979). Differentiation among some acholeplasmas by nucleic acid homology. Current Microbiology 2, 91-94.

Aulakh, G. S., Stephens, E. B., Rose, D. L., Tully, J. G. \& Barile, M. F. (1983). Nucleic acid relationships among Acholeplasma species. Journal of Bacteriology 153, 1338-1341.

BARILE, M. F. (1973). Mycoplasmal flora of simians. Journal of Infectious Diseases 127, S17-S20.

Bove, J. M. \& Salllard, C. (1979). Cell biology of spiroplasmas. In The Mycoplasmas, vol. 3, Plant and Insect Mycoplasmas, pp. 83-153. Edited by R. F. Whitcomb \& J. G. Tully. New York: Academic Press.

Bove, J. M., Saillard, C., Junca, P., DeGorceDumas, J. R., Ricard, B., Nhami, A., Whitcomb, R. F., Williamson, D. \& Tully, J. G. (1982). Guanine-plus-cytosine content, hybridization percentages, and EcoRI restriction enzyme profiles of spiroplasmal DNA. Reviews of Infectious Diseases 4, S129-S136.

Chandler, D. K. F., Razin, S., Stephens, E. B., Harasawa, R. \& Barile, M. F. (1982). Genomic and phenotypic analyses of Mycoplasma pneumoniae strains. Infection and Immunity 38, 604-609.

Darai, G., Flugel, R. M., Zoller, L., Matz, B.,
Krieg, A., Gelderblom, H., Delius, H. \& Leach, R. H. (1981). The plaque-forming factor for mink lung cells present in cytomegalovirus and HerpesZoster virus stocks identified as Mycoplasma hyorhinis. Journal of General Virology 55, 201205.

Darai, G., Zoller, L., Matz, B., Delius, H., Speck, P. T. \& Flugel, R. M. (1982). Analysis of Mycoplasma hyorhinis genome by use of restriction endonucleases and by electron microscopy. Journal of Bacteriology, 150, 788-794.

Elmahi, M. M., Ross, R. F. \& Hofstand, M. S. (1982). Comparison of seven isolates of Mycoplasma meleagridis. Veterinary Microbiology 7, 61-76.

JORDAN, F. T. W. (1979). Avian mycoplasmas. In The Mycoplasmas, vol. 2, Human and Animal Mycoplasmas, pp. 1-48. Edited by J. G. Tully \& R. F. Whitcomb. New York: Academic Press.

Pollack, J. D., Razin, S. \& Cleverdon, R. C. (1965). Localization of enzymes in Mycoplasma. Journal of Bacteriology 90, 617-622.

Razin, S. \& RotTeM, S. (1967). Identification of mycoplasma and other microorganisms by polyacrylamide-gel electrophoresis of cell proteins. Journal of Bacteriology 94, 1807-1810.

RAZIN, S., KNYSZYNSKI, A. \& Lifshitz, Y. (1964). Nucleases of mycoplasma. Journal of General Microbiology 36, 323-331.

Razin, S., Harasawa, R. \& Barile, M. F. (1983). 
Cleavage patterns of the mycoplasma chromosome by restriction endonucleases as indicators of genetic relatedness among strains. International Journal of Systematic Bacteriology 33 (in the Press).

Rhoades, K. R., Phillips, M. \& Yoder, H. M., JR (1974). Comparison of strains of Mycoplasma gallisepticum by polyacrylamide gel electrophoresis. Avian Diseases 18, 91-96.

Somerson, N. L., Reich, P. R., Chanock, R. M. \& Weissman, S. M. (1967). Genetic differentiation by nucleic acid homology. III. Relationship among mycoplasma, L-forms, and bacteria. Annals of the New York Academy of Sciences 143, 9-20.

Stephens, E. B., Aulakh, G. S., Rose, D. L., Tully, J. G. \& BARILE, M. F. (1983). Intraspecies genetic relatedness among strains of Acholeplasma laidlawii and of Acholeplasma axanthum by nucleic acid hybridization. Journal of General Microbiology 129, 1929-1934.

SUbCOMMITTEE ON THE TAXONOMY of Mollicutes, InTERNATIONAL COMMITTEe ON SyStematic BaCteRIOLOGY. (1979). Proposal of minimal standards for description of new species of the class Mollicutes.
International Journal of Systematic Bacteriology 29, 172-180.

Taylor-Robinson, D., Tully, J. G., FurR, P. M., Cole, R. M., Rose, D. L. \& Hanna, N. F. (1981). Urogenital mycoplasma infections of man: a review with observations on a recently discovered mycoplasma. Israel Journal of Medical Sciences 17, 524530.

Tully, J. G. \& Razin, S. (1969). Characteristics of a new sterol-nonrequiring mycoplasma. Journal of Bacteriology 98, 970-978.

Tully, J. G., Whitcomb, R. F., Clark, H. F. \& Williamson, D. (1977). Pathogenic mycoplasmas: cultivation and vertebrate pathogenicity of a new spiroplasma. Science 195, 892-894.

Tully, J. G., TAYlor-Robinson, D., Cole, R. M. \& Rose, D. L. (1981). A newly discovered mycoplasma in the human urogenital tract. Lancet 1, 1288-1291.

Tully, J. G., TAYlor-Robinson, D., Rose, D. L., COle, R. M. \& BOVe, J. M. (1983). Mycoplasma genitalium, a new species from the human urogenital tract. International Journal of Systematic Bacteriology (in the Press). 